\title{
Submerged Layers of Slovenian Identity in Krissy Kneen's Writing ${ }^{1}$
}

\author{
Igor Maver
}

\begin{abstract}
The article for the first time ever explores the recent non-fiction and poetry by the contemporary Australian writer Krissy Kneen, who has Slovenian roots through her maternal grandmother. Kneen's writing, a literary tribute to her late grandmother Dragitca (Dragica Marušič), shows a desire to come to terms with her partly 'Slovenian' gut microbiome and DNA, as she herself claims. They, in her view, along with the other elements in the process of identity formation, interestingly importantly help to constitute an ethnic identity and, for that matter, any personal identity. This makes her writing very original within the extant diasporic literary production.
\end{abstract}

Keywords: Krissy Kneen, Slovenian-Australian diaspora, Australian literature

1 The author acknowledges the financial support from the Slovenian Research Agency (Intercultural Literary Studies, research core funding No. P6-0265). 


\section{A LITERARY HOMAGE TO KNEEN'S MATERNAL SLOVENIAN GRANDMOTHER DRAGITCA}

Krissy Kneen (born in 1968) is a Brisbane-based Australian bookseller and writer. Her first book of poems was in 2014 awarded the Thomas Shapcott Poetry Prize and will be discussed in a separate study in the next issue of this journal. It is entitled Eating My Grandmother: A Grief Cycle (Kneen, 2015) and is dedicated to her deceased grandmother Dragi(t)ca Marušič, known in Australia as Lotty Kneen (1916-2014), as a fine poetic and very personal homage. The first poem "Prelude" symbolically sums up the speaker's grief at the loss of her deceased grandmother. It is interesting that most of the poems deal with a very physical, bodily way of coming to terms with the loss, which also shows how she remembers certain episodes from their life and experiences together.

Kneen is the author of short stories, her first novel, a Steeplechase, was published in 2013, and more recently the novels An Uncertain Grace and Wintering. In Griffith Review 58 (Storied Lives/The Novella Project V series), published by Griffith University in Brisbane in 2017, there were some of the most prestigious Australian contemporary authors of various generations featured, for example Frank Moorhouse, Cassandra Pybus, Kristina Olsson, and Krissy Kneen. In Kneen's non-fiction published there, "How to preserve a turnip / And other whispers in my genes" (Kneen 2017), she gives a fascinating and decidedly new take on the mostly painful search for her ethnic background. In her case, a Slovenian diasporic heritage has been for several generations submerged in the deepest layers of her personality and, as she hastens to point out, particularly her body and microbiome (cf. also Maver 1994; 2006). She traces back the birth of her great-great grandmother Anastasia nearby Trbinc Hill in the South-Eastern part of Slovenia, near the village Mirna on the Mirna river in the Dolenjska region, where her maternal stock originally comes from.

Right from the beginning she uses expressions taken from the military language to somehow shock the reader and introduces a concept which is new and original in diaspora studies. To indicate ethnic belonging she contends that invasion, colonization of armies, bacterial soldiers characterizes the birth of every new person, describing how the baby, her great-great grandmother, for example, was invaded by the microorganisms and bacteria, which gave the new-born baby, somewhere outdoors in the snow in Slovenia, a sense of identity. It is an invasion that starts with birth and that one cannot escape until one's death, a fascinating view on identity and ethnic belonging, which is inscribed in one's intestinal flora and literally in the DNA of a person as well. Identity that asserts itself also through the food preparation and processing using the typically Slovenian technique and tradition of "preserving turnip in the pickle" and making a delicious dish bujta repa with it, as we learn later in the text: 
The life teeming inside. A colonization, armies of tiny creatures trudging along the complexities of a digestive tract, pausing only to battle with each other. Tiny genocides, whole families ambushed and murdered. The cultural mix of micro-organisms changing and shifting in the time it took to stretch out a tiny perfect spine and shiver little fingers into fists. The bacteria that melted onto that fresh skin with the snow was ancient life with a history as old as the mountain itself; tiny soldiers that had multiplied on each new blade of grass; immigrant armies dropped by the shit of a bird or carried on cat scat. By the time this baby opened her teeming lungs and uttered a shrill vibrating note there were more bacterial soldiers than there were baby cells inside the tiny form. She was already outnumbered before her life had properly begun. (Kneen 2017,169)

The baby born, Anastasia, was Kneen's grandmother's grandmother. She in turn later bore Perina (a well-known Dalmatian Croatian name derived from the male form for Petar /Peter):

Anastazija, my grandmother's grandmother. Anastazija, who bore Perina, who bore Dragitca who bore Wendy, who bore me, Krissy. Krissy Kneen. (170)

There follows a passage on how the supposed magic quality is handed down on the matrilinear line, Kneen's great-great-mother was "a witch", so was her grandmother Dragitca Marusic (Dragica Marušič, known in Australia as Lotty Kneen that lived during 1916-2014) and so is she: "Not your mother. But you. Your white streak. You will have the magic too" (171). We get to see Kneen as being downright obsessed with her grandmother, in the positive send of the word, who had left her the magic powers and the woman's strength in the family. She is the strongest one, rather than feeling weak and gentle, as she has been considered so far, she survives her real-life serious sickness: "In the midst of pain and in this mythic remaking of myself through her, I am reborn. I become myself” (172).

The author introduces the reader to her grandmother Dragitca, who was, we learn, obsessed with the fairytales in general and Slovenian folklore, particularly the Krivopeta (Krivopete in the plural form): "One particular creature of lore is the Krivopeta. This creature is one of the wild women of Slovenia. There are several wild women (and wild men) characters, but the Krivopete can be identified by their feet, which are turned backwards, facing the place they have just come from" (172). Dragitca would read the fairytales to her granddaughter Krissy, about the Slovenian faeries Rojenice, Sojenice, Podmének (a changeling child), and those by Perrault, Brothers Grimm, Andersen, even The Egyptian Book of the Dead, since Dragitca was very much influenced by Egypt and her long stay there, as well as her Egyptian husband. Kneen was immersed into the fairytales through this strong female bond and her grandmother created many papier-mâché life-size 
figures of individual characters, which are still preserved in a storage somewhere in Australia, in the so-called Dragonhall that no one saw and were never used for people to visit (some of these reminiscences are also to be found in Kneen's work Affection from 2009). Kneen is the one who was chosen by her to carry on this fascination and she does have her grandmother's literary magic streak, since she has become herself an accomplished writer, an artificer of life: "The stories were passed down from swaddled girl-child to swaddled girl-child along with the bacteria passed from skin to skin" (173). She teaches her granddaughter various recipes, making cheese, gnocchi, but she never taught her to preserve the whey, as a Krivopeta, something left for her still to figure out.

The author indulges in the scientific description of her identity and indebtedness to her matrilinear stock. Her microbiome which ultimately defines her body, not just the culture or language, former experiences of her ancestors, she believes, are inscribed in her DNA, as part of her genetic material which lay inactive some of the time, "I am more other than I am myself. I am driven by forces that are so small that they are out of sight and out of mind" (176). The description of her microbiome, in real life, which cannot be seen but definitely defines her as a person, surprises the reader and adds to her search for the ethnic roots, it becomes belonging, which is longing, too: "The biological stuff that is inside me at its tiniest level is my DNA, but that cluster of DNA is in the minority. The stuff that is me and of my ancestors is spliced together with pieces of viral invadors that have been co-opted into my genetic cohort, and even with these foreign building blocks, the bricks that are mine are outnumbered by the stuff that is bacterial" (176).

She further describes her grandmother Dragitca's travel to Egypt all alone as a child, then how she had to flee Alexandria in 1956, after Naser's coming into power, the exodus of the foreign Egyptianized community there, including her grandparents, and how she arrived to England with two small children. She had earlier married an Egyptian man of mixed parentage, wearing a wedding dress from Paris, which she often pointed out to her as it was really important to her, as a sign of prestige, for nationalities were important in Alexandria, then a truly multicultural and thriving city, where especially British and French were the highest rated ones. Kneen's grandfather, a mystery man and not much spoken about, had a British passport, worked at the British embassy, and had a dark olive skin. Over a thousand Jews were also arrested and forced into exodus in 1956-7 and Kneen desperately tries to scientifically determine, in her text, whether or not she may actually be Jewish, a "Jewessa", like one of their maids. There were long silences in the family and she wants to come to the bottom of her true origin. Of course, the result of the scientific DNA test is inconclusive and she can just see her grandmother Dragica snickering somewhere, like a Krivopeta, leaving her family roots and origin deliberately somewhat secretive and inconclusive. Then, she wonders, 
if Dragitca was perhaps a member of the Kindertransport, known as an attempt to rescue Jewish children out of Nazi Germany and some other countries just before the outbreak of the Second World War, but she had actually never been in these countries and always insisted she had been born in a no man's land, Slovenia, the Western part being under the Italian rule until 1943: "Slovenia', she would say when pushed. 'No man's land, Slovenia', as if it were a city within a country within her imagination" (182).

The author in her non-fictional memoir reminiscing about Dragitca then describes the Krivopeta Slovenian folk legend in more detail, "the wild women of Slovenia" (184), also known in the border region of Resia, today on Italian ground in the Alps, where the Slovenian minority lives. Especially complex is Krivopeta's attitude to men: "The Krivopeta tolerates the man, is sometimes affectionate towards him, but there is always a distance. Her feet are always facing backwards towards her life in the mountains when she was happily alone" (185). Kneen describes herself as a woman of science and firmly believes that the microbiome has a very important effect on the whole of our bodies. In this regard her grandmother talked about her own experience of learning a typical Slovenian dish from her own grandmother Anastasia, the preparation of bujta repa (literally in Slovenian translation "slaughtered turnips", complemented by the meat of slaughtered pigs during the pork-slaughter time in the fall): "The fermented pickled root vegetables would be grated and added to a big pot of bones and meat with some millet and whole black pepper and roux" (187). This dish is best known in the Slovenian Prekmurje region near the border with Hungary and it is traditionally prepared during the time of pig-slaughter in the fall. For Kneen the preparation of this dish requires some magic and she was chosen by her grandmother to carry on the 'secret' of the preparation of an excellent bujta repa: "The magic skips a generation. Your mother doesn't have it but I see it in you. It lights up your skin when you sleep. You need to be trained just as my grandmother trained me when I was your age. I need to pass the secret on to you" (187).

\section{WHO AM I?}

Kneen in her text skips over to the definition of herself in scientific terms. She claims that we people are 43 per cent human and 57 per cent other, consequently, she concludes, her body's cells are outnumbered by non-human organisms. And these organisms must be fed. In prepared various foods and especially bujta repa there is one phrase that is being repeated over and over in her head, like in much of foodie literature: "the magic is in the hands of the cook. The magic is in the hands" (188). The scientific result that she might be partly an Ashkenazi Jewish person is 
inconclusive and she admits to having kept secret the fact that Dragitca was from Slovenia, because she might be Jewish and even 'a witch'. Even after her death, the stormy weather, which Krivopete are known to be able to control, reminded her of her grandmother's presence. Is she really free of her now that she is gone for ever. We are never completely free of our ancestry and the past experiences and genetic code inscribed in us. Not really, the secrets of her origin, her obstinate search and inconclusive scientific answers testify to the opposite, despite her claim:

I am no longer a captive of my grandmother's steely will. She is dead and I am free. I am free to find out who I am. I am free to find out who she was.

Anastazija; Dragitca; me. (190)

The author is at the end of the text preparing pickled cabbage, sauerkraut. She feels there is something meditative about this, a rhythm to it. She knows she is doing this because of her gut feeling, one could say, gut bacteria, the vagus nerve, but despite the insistence on science she insists that "the magic is in the hands"; it is what you can do with yourself here and know, differently, even if repeating the patterns of your ancestors, in her case those of her grandmother Dragitca. Her search for Slovenian roots is not ended, it is an ongoing process in the making, in the magic of discovering who she is, an Australian, a Slovenian, an Ashkenazi Jewess, a woman, a writer.

\section{SLOVENIAN WOMEN OF ALEXANDRIA/ALEKSANDRINKE}

Already in Griffith Review 58 in 2017 Krissy Kneen, in her creative non-fiction long piece, mentions in passing the phenomenon of the Aleksandrinke, the Slovenian women of Alexandria in Egypt, where they had migrated from Slovenia for economic reasons, to work as nannies, often leaving behind their families and their own small children, their husbands, who were not able to provide for them. However, in Griffith Review 66 published in 2020, however, Kneen published her memoir "Aleksandrinke, Mapping a movement of women", Griffith Review 66 memoir (https://www.griffithreview.com/articles/aleksandrinke/), based on her visit to Slovenia just over a year ago. Her grandmother had that experience as a child of an Aleksandrinka (in singular form) and Kneen tries to relive and re-experience her submerged Slovenian identity, where the phenomenon of the Slovenian women of Alexandria is the central focus of her memoir. She begins the narrative of her grandmother Dragitca's life story by presenting the old Slovenian originally folk tale and legend about the Beautiful Vida (Lepa Vida), later on also dealt with individually by major Slovenian writers, which is used as an appropriate 
parallel to the fate of the Aleksandrinke between the two world wars until 1956 in the Primorska region on today's border with Italy, the area then, after the dissolution of the Austro-Hungarian empire, under the Italian rule. The old folk song of the Beautiful Vida is a song of yearning, sorrow and regret and is also often considered a symbol of Slovenian diaspora in abstracto. Vida leaves for Spain, beyond the seas, where the dark-skinned man brings her to be the nanny of the little prince, the very son of the Queen of Spain, but she had to leave her old husband and sickly child behind, who eventually die: she too slowly languishes away full of sorrow on foreign ground, although we do not get informed about her death. This myth from the time of the Moorish invasions of Adriatic cities during the 9th and 11th centuries is deeply rooted in Slovenian literary tradition in several versions. The author of the memoir remembers her grandmother Dragitca's adamant pleas not to the search for the submerged layers of ethnic identity, for the other "homeland" as well, not only Australia:

Throughout her life she was tight-lipped about her background. I could glean only fragments of her history. She was born in Slovenia. When she was just a child, she was put on a train. She was travelling alone. Somehow, she ended up in Egypt.

No. We had no relatives outside the small cluster of immediate family.

No. We had no history.

Look forward, she told me. Never look back.

Now I gaze into the plastic container of ashes.

I look back. I am trying to catch a glimpse of my grandmother sitting on the train that took her away from her home in Slovenia. A stuttering light and shade of tantalising scraps.

She had forbidden me from asking for stories about her past. She had forbidden me from setting out on my own quest to find a homeland.

Now that she is dead I feel like a caged bird, waking one day to find the cage door open as I stand safely inside, looking out, afraid to spread my wings and fly. (GR 66)

In the small Ljubljana bookstore on a beautiful Baroque square, which Kneen liked so much during her stay in Slovenia in 2018, and near where we used to meet in one of the famous and pleasant Ljubljana cafés, she got hold of an English translation of the book on Aleksandrinke, the Slovenian women of Alexandria: she imagines being part of something greater that she had ever imagined, something in her genes and guts, her deep, submerged layer of (Slovenian/Jewish) identity. 
If you wanted a strict nanny who would be feared by your children, you hired a British nanny. If you wanted a nanny your children would grow to love, you chose a Slovene.

In Egypt, having a Slovene nanny became a symbol of a certain elevated social status. Rich women from all cultures in Alexandria began to seek them out. Word was carried home by aunts and cousins coming back to visit their families for feast days: there was work for young Slovene women in Egypt, and it was good, profitable work. All you had to do was leave your family, your community, your culture behind. All you had to do was take a leap of faith across the ocean and your family would be saved from the hardship of extreme poverty.

The Slovene women of Alexandria were attaining the reputation of being uncommonly good nannies. They spoke several languages, including perfect Italian, and were quick to learn others. They were Catholics, which was important to the rich Italian mothers. They were hardworking, and they were known to be kind. If you wanted a strict nanny who would be feared by your children, you hired a British nanny. If you wanted one your children would grow to love, you chose a Slovene.

And thus the Slovene nanny came to symbolise a certain elevated social status, and rich women from all cultures in Alexandria began to seek them out. Word was carried home by aunts and cousins returning for feast days to visit their families. There was work for young Slovene women in Egypt; good, profitable, well-respected work. All you had to do was leave your family, community and culture behind. All you had to do was take a leap of faith that would carry you across the ocean, and your family would be rescued from hardship.

In my grandmother's village, Miren, there is the bora, the strong wind that sweeps across the karst, ripping the roof tiles off houses and scouring the dry mountain passes. But with every hardship comes a blessing, and the bora brings the perfect weather for drying prosciut. The sausages and prosciut from my grandmother's village are prized for their wind-dried sweetness. Every father has a cellar hung with the finest meats in the land.

Along with the prosciut [Slovenian pršut], language became a luxury that the villagers under Italian rule could no longer afford. Slovene was whispered in the privacy of the home, but Italian was the language spoken in schools, in businesses, on farms. Speaking Slovene in public could lead to torture or death. (GR 66)

While in Ljubljana, I talked with Krissy about Dragitca's departure for Egypt, which took place from Trieste, the then major port and Mediterranean hub. I suggested she visits Trieste and the famous Molo San Carlo/Audace, which is where the diaspora was leaving from into the wide world, earlier during the Austro-Hungarian empire and later during the Kingdom of Yugoslavia: 
It is a relief to be free of the car in the narrow one-way streets of Trst, which is now called by the Italian name, Trieste. We walk down towards the water. Everything here leads downwards to the bay, as if the whole landscape is poised to leave. The sweep of Trst is just one long farewell.

I walk towards the pier. It juts a long way out into water that is steely grey and as calm as if it is sleeping. We walk along its old, marked surface, my feet in my grandmother's footprints, lock step.

This is where the boats pulled in, the huge ships, bound for Egypt. My grandmother was a child, maybe ten, maybe younger. She had been put onto a train, heading for the coast, alone.

I feel my eyes begin to prick with tears. How would it feel to say farewell like this? Farewell to all you have known.

She would never return. (GR 66)

There was some sort of shame present about the women of Alexandria. Some have indeed left at home their children, some, however, have not, as is evidenced by the stories of children belonging to Aleksandrinke that grew up in Egypt. Some of them and their mothers of course ended up even further away from home, in Canada or Australia, as is the case with Kneen's grandmother Dragitca. She was put on a train from Slovenia as a child and ended up in Egypt where she rejoined her mother, an Aleksandrinka, and she was never to see home again and ended up in Australia:

I'M NOT SURE what I can do to fill the gaping hole that her death has opened up in my world.

Throughout her life she was tight-lipped about her background. I could glean only fragments of her history. She was born in Slovenia. When she was just a child, she was put on a train. She was travelling alone. Somehow, she ended up in Egypt.

No. We had no relatives outside the small cluster of immediate family.

No. We had no history.

Look forward, she told me. Never look back.

Now I gaze into the plastic container of ashes.

I look back. I am trying to catch a glimpse of my grandmother sitting on the train that took her away from her home in Slovenia. A stuttering light and shade of tantalising scraps.

She had forbidden me from asking for stories about her past. She had forbidden me from setting out on my own quest to find a homeland. (GR 66) 
Of course, it is absurd to feel shame about the Aleksandrinke, which is how the village milieus would sometimes see them. The phenomenon only shows in what a plight the people and especially the women from the Primorska Littoral region were in at the time, economically, as they had little else left to do other than leave for Alexandria and even abandon their loved ones, becoming breadwinners instead of their men.

\section{CONCLUSION}

The concept of Australia has been a work in progress for quite some time, from the Eurocentric point of view at least from 1788 onwards. Its culture has recently been redefined through the narratives and art in general. Krissy Kneen, the author, too, has been questioning and (re)defining herself as a person, writer, woman, a Slovenian-Australian, through her literary work, often shortlisted for prizes and awarded an important prize for a poetry collection written in a completely new diasporic literature fashion. Creating narratives is a way of mythopoesis and forging myths, which we all need to identify with (since we know that they more than just myths but flickers of reality as well), about Australia and its identity, Australia as an imagined community (Anderson 2016), a felicitous composite of various ethnic groups, including Slovenians (Maver 2010), cultures, historical events and social movements in the past, and much more. Kneen's literary contribution in her search for the roots in the edifying literary monuments to her Slovenian grandmother, is an original and successful step in this direction.

\section{BIBLIOGRAPHY}

Anderson, Benedict. 2016 [1983]. Imagined Communities: Reflections on the Origin and Spread of Nationalism. London: Verso.

Kneen, Krissy. 2015. Eating My Grandmother. St Lucia: UQP. .2017. "How to Preserve a Turnip and other Whispers in My Genes". Griffith Review 58, ed. by Julianne Schultz. South Brisbane/Melbourne: Griffith University and Text Publishing.

.2020. "Aleksandrinke, Mapping a movement of women", Griffith Review 66. (https://www.griffithreview.com/articles/aleksandrinke/)

Maver, Igor. "The Mediterranean in Mind: Bert Pribac, a Slovene Poet in Australia”. Westerly, No. 39.4. (1994): 123-29. .2006. Critics and Writers Speak: Revisioning Post-Colonial Studies. Lanham, MD: Lexington Books/Rowman and Littlefield. 
.2010. "Slovenian Migrant Literature in Australia: An Overview with a Reading of the Work of Jože Žohar". In Australian Made: a Multicultural Reader, edited by Sonia Mycak and Amit Sarwal, 173-199. Sydney: Sydney University Press.

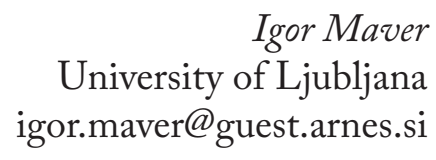

(c) (1) ()

\section{Slovenske identitetne plasti v pisanju Krissy Kneen}

Članek prvikrat obravnava pisanje sodobne avstralske pisateljice Krissy Kneen, ki ima slovenske korenine. Tovrstno pisanje, književni poklon njeni pokojni babici Dragici Marušič (znani kot Lotty Kneen), kaže, da se želi sprijazniti s svojim slovenskim mikrobiomom in DNK. Ta po njenem mnenju predstavljata pomembno plast etnične identitete oziroma vsakršne identitete posameznika.

Ključne besede: Krissy Kneen, slovensko-avstralska diaspora, avstralska književnost 